\title{
FACIAL HEMANGIOSSARCOMA IN A BLUE-FRONTED AMAZON PARROT (Amazona aestiva)
}

\author{
[Hemangiossarcoma facial em papagaio verdadeiro (Amazona aestiva)]
}

\author{
Guilherme Augusto Marietto-Gonçalves ${ }^{1 *}$, Fabrizio Grandi ${ }^{2,3}$ \\ 1 Avian Pathology Laboratory, Sao Paulo State University, Brazil; \\ ${ }^{2}$ Laboratory of Investigative and Comparative Pathology, Sao Paulo State University, Botucatu-SP, Brazil; \\ ${ }^{3}$ Department of Pathology, Medical School, Sao Paulo State University, Botucatu-SP, Brazil;
}

\begin{abstract}
Here we describe the first case report of an hemangiosarcoma in a male Blue-fronted amazon parrot (Amazona aestiva). The mass was localized near the inferior portion of the right orbit. A fine needle aspiration biopsy (FNAB) was performed and a presuntive diagnosis of hemangioma/hemangiosarcoma was established. Further histopathological evaluation revealed a mesenchymal neoplasm composed basically by well formed vascular channels lined by pleomorphic endothelial cells. Thus, the final diagnosis was a well-differentiated cutaneous hemangiosarcoma.
\end{abstract}

Keywords: Hemangiossarcoma, birds, Amazon parrot, Pathology.

RESUMO - Aqui se descreve o primeiro caso de hemangiossarcoma em um macho de Papagaio verdadeiro (Amazona aestiva). A massa estava localizada próxima a porção inferior da órbita direita. Uma aspiração utilizando agulha fina foi realizada e o diagnóstico presuntivo de hemangioma/hemangiossarcoma foi estabelecido. Em seguida, a avaliação histopatológica revelou uma neoplasia mesenquimal composta, basicamente, por canais vasculares bem formados alinhados com células endoteliais pleiomórficas. Desse modo, o diagnóstico final foi de hemangiossarcoma cutâneo bem diferenciado.

Palavras-Chave: Hemangiossarcoma, pássaros, papagaio verdadeiro, patologia.

\footnotetext{
${ }^{*}$ Corresponding author: gmarietto_ornito@fmvz.unesp.br.
} 


\section{INTRODUTION}

Hemangiosarcoma also known as angiosarcoma or malignant hemangioendothelioma is a malignant neoplasm. Is characterized by pleomorphic endothelial cells aligned on multiple collagen trabeculae that forms bloodfilled vascular spaces of variable sizes (Maxie, 2007). It is locally invasive and multicentric tumor that tends to present with inflammation and necrosis. It may occur primarily in the skin or as a result of metastasis from a visceral primary source, and is commonly found in adult and old animals (Jones et al., 1997; Reavill, 2001; Maxie, 2007). Here we describe the first case report of an hemangiosarcoma in a bluefronted amazon parrot (Amazona aestiva).

\section{CLINICAL REPORT}

An 15-year-old, 320g captive male Amazona aestiva was presented for examination after a progressive facial enlargment localized near the inferior portion of the right orbit. On physical evaluation, a mass presumably extending into subcutaneous, measuring $1,5 \times 0,8 \mathrm{~cm}$, adhered to deep tissues, firm, warm, reddish, and nonulcerated was noted in aforementioned region. Clinically, the animal was anorexic and depressed. Samples for cytopathologic examination were obtained by fine needle aspiration biopsy (FNAB) from 2 different areas using a fine needle (22G1 1/4") and a $10 \mathrm{ml}$ syringe. Previously to cytological examination, the animal was sedated with an subcutaneous administration of ketamine $\mathrm{HCl}(25 \mathrm{mg} / \mathrm{Kg}$ IM,). The collected material was spread on histological slides, air-dried, methanol fixed, and stained with Giemsa. The smears were highly cellular and composed predominately by erythrocytes, heterophils and lesser amounts of monocytes. A presuntive diagnosis of hemangioma or hemangiosarcoma was stated. After routine anesthetic procedures (atropine sulfate $0,02 \mathrm{mg} / \mathrm{kg}$ IM. ketamine $\mathrm{HCl} 20 \mathrm{mg} / \mathrm{kg}$ and midazolam $4 \mathrm{mg} / \mathrm{kg} \quad \mathrm{IM}$ ) and local antisepsis, the animal was submitted to a excisional biopsy in order to remove the mass. The lesion was not completely removed during surgery due to the deep adherence to the underlying tissues which in turn could compromise postoperative recovery.

The tumor was fixed in $10 \%$ neutral-buffered formalin, trimmed, routinely processed and embedded in paraffin. Routine histological sections $4 \mu \mathrm{m}$ in thickness were stained with
Hematoxilin and Eosin (HE) in order to achieve a definitive diagnosis. Histologically, the mass were restricted to dermis, highly cellular and had an expansible growth. The neoplastic cells were plump to fusiform and aligned on collagen trabeculae that formed an anastomosing meshwork of blood-filled channels of variable size. The cells were moderately pleomorphic with and eosinophilic discrete cytoplasm, oval nuclei, and distinct nucleoli (Figure 1). The vascular spaces were not completely enclosed by endothelial cells, and blind-end trabeculae could be observed. Some vessels were filled by adherent thrombi. Rare mitotic figures could be seen. Based on those findings, the final diagnosis was well differentiated cutaneous hemangiosarcoma. Finally, the animal died two weeks after the procedure due to surgical complications such uncontrollable nasal bleeding and difficulty feeding.

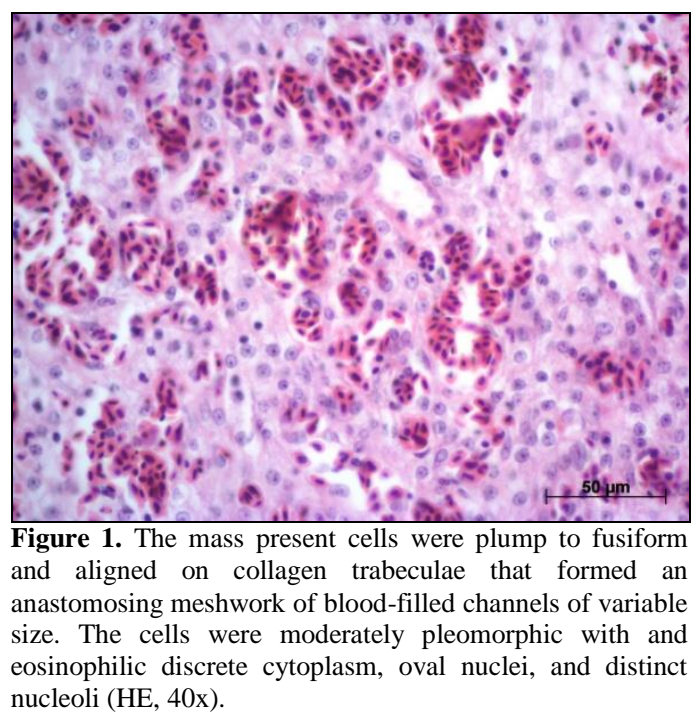

\section{DISCUSSION}

In psittacines birds the neoplasm has been described in Melopsittacus undulates (Freeman et al., 1999), Pionus spp., Agapornis spp., Psittacus erithacus (Reavill, 2004), Primolius auricollis (Reavill, 2001), Nymphycus hollandicus (Sledge et al., 2006), Amazona ochrocephala oratrix (Hanley, 2005), A. farinosa (Rossi, 1998), A. amazonica (Mickley et al., 2009), and also already described in $A$. aestiva (Godoy et al., 2009).

In avian, the most common affected anatomic areas are the skin of peripheral beak region and cloaca, neck, dorsum, hind and forelimbs (Campbell, 1986; Reavill, 2001; Schmidt et al., 
2003). Some internal organs such liver, bones, and ovary can also be affected (Rossi, 1998; Hanley, 2005; Mickley et al., 2009). Surgical excision of cutaneous tumors in domestic birds is usually curative with a good prognosis if no metastases are present (Bauck, 1997; Maxie, 2007). Grossly, the tumor mass can present as eryhtematous areas with black spots due to the inflammatory process associated with multiple necrotic foci which can lead to follicle loss (Campbell, 1986; London \& Vail, 1996). Clinically ill birds can present lethargy, anorexia, weight loss, edema, dyspnea, petechial hemorrhage, and anemia. The last two signs are secondary to trauma of the neoplastic mass (Latimer, 1994).

Definite diagnosis based on cytology can be very difficult to impossible since the smears contain only blood and rarely pleomorphic neoplastic endothelial cells (Campbell, 1986). Despite this, a presuntive diagnosis of hemangiosarcoma can be readily made based on FNAB. However, histopathological analysis is considered the definitive diagnostic method allowing differentiation between vascular neoplasms, hematomas, filariosis, cutaneous cysts and Poxvirus infection in birds.

\section{REFERENCES}

Bauck, L. 1997. Avian Dermatology. In: Altman RB, Clubb, S.L., Dorrestein, G.M., Quesenberry, K. (Eds). Avian Medicine and Surgery. Philadelphia, WB Saunders Company, p.557-568.

Campbell, T.W. 1986. Neoplasia. In: Harrison, G.J., Harrison, L.R. (Eds). Clinical Avian Medicine and Surgery. Philadelphia,WB Saunders Company, p.500-508.

Freeman, K.P., Hahn, K.A., Adams, W.H. 1999. Radiation therapy for hemangiosarcoma in a budgerigar. J. Avian Med. Surg. 13(1):40-44.

Godoy, S.N. 2006. Psittaciformes (arara, papagaio, periquito). In: Cubas, Z.S., Silva, J.C.R., Catão-Dias, J.L.
(Eds). Tratado de Animais Selvagens. São Paulo, Roca, p.247-248.

Godoy, S.N., Alves, V.A.F., Kanamura, C.T., Matushima, E.R. 2009. Principais processos neoplásicos encontrados em psitacídeos mantidos em cativeiro. Pesq. Vet. Bras. 29(6): 445-451.

Hanley, C.S., Wilson, G.H., Latimer, K.S., Frank, P., Hernandez-Divers, S.J. 2005. Interclavicular hemangiosarcoma in a Double yellow-headed amazon parrot (Amazona ochrocephala oratrix). J. Avian Med. Surg. 19(2):130-137.

Jones, T.C., Hunt, R.D., King, N.W. 1997. Veterinary Pathology. 6th ed. Baltimore, Willians and Wilkins, 1392p.

Latimer, K.S. 1994. Oncology. In: Ritchie, B.W., Harrison, G.J., Harrison, L.R. (Eds). Avian Medicine: Principles and Applications. LakeWorth, Wingers Publishing, p.640-672.

London, C.A., Vail, D.M. 1996. Tumor biology. In: Whithrow, S.J., Macewen, E.G., (Eds). Small Animal Clinical Oncology. Philadelphia, WB Saunders Company, p.16-31.

Maxie, M.G. 2007. Jubb, Kennedy and Palmers: Pathology of Domestic Animal, 5th ed. Philadelphia, Saunders Elsevier.

Mickley, K., Buote, M., Kiupel, M., Graham, J., Orcutt, C. 2009. Ovarian hemangiosarcoma in an Orange winged amazon parrot (Amazona amazonica). J. Avian Med. Surg. 23(1):29-35.

Reavill, D.R. 2001. Pet bird oncology. In: Proceedings of the Association of Avian Veterinarians conference. Avian Specialty Advanced Program: Orlando, FL; 2011:29-43.

Reavill, D.R. 2004. Tumors of pet birds. Vet. Clin. North. Am. Exot. Anim. Pract. 7(3):537-560.

Rossi G. 1998. A poorly-differentiated hepatic haemangiosarcoma in a Amazon farinosa parrot. Avian Pathol. 27(4):427-430.

Schmidt, R.T., Reavill, D.R., Phalen, D.N. 2003. Pathology of Pet and Aviary Birds. Ames, Iowa State Press, 234p.

Sledge, D.G., Radi, Z.A., Miller, D.L., Lynn, B.S. 2006. Subcutaneous Haemangiosarcoma in a Cockatiel (Nymphicus hollandicus). J. Vet. Med. A Physiol. Pathol. Clin. Med. 53(6):293-295. 